\title{
Monitoring and Assessing our Nation's Water Quality
}

\begin{abstract}
The U.S. Geological Survey (USGS) has monitored and assessed the quality of our Nation's streams and ground water since its inception in 1879. Today, USGS provides information on issues such as the suitability of water for public supply and irrigation, aquatic ecosystem health, effects of agriculture and urbanization on water resources, acid rain, and disposal of radioactive waste. Through the integration of its six major waterquality programs (described on pages 5 and 6), the USGS continues its mission to provide timely and relevant waterresources data and information that is freely available to all levels of government, non-governmental organizations, industry, academia, and the general public. The information provides a scientific basis for decision making related to resource management and restoration, and how we as individuals interact with our environment.
\end{abstract}

\section{Characteristics of USGS Water Quality Activities Provide Unique Perspective}

USGS programs provide a unique perspective on water-quality conditions, complementing much of the work conducted by local, state, and other Federal agencies, the private sector, and the university community. Six common characteristics of these programs are described.

First, USGS programs typically evaluate ambient water-quality conditions over long time scales with a regional and national perspective. This makes it possible to detect changes across time and space and to provide insights into natural and human factors that may be responsible for those changes. USGS programs are designed to address issues at several scales. Some address local issues in a particular stream or aquifer or in a particular county, while others look at broad regional systems that cross jurisdictional boundaries.

Second, USGS programs recognize the totality of the resource, including all components of the hydrologic cycle and the interconnections among these components. USGS addresses conditions in ground water, in the unsaturated zone, and in streams, lakes and reservoirs, and recognizes surface-water and groundwater interactions and atmospheric contributions. Inclusion of all hydrologic components allows a full accounting of all available sources, increases understanding of factors controlling waterquality degradation, and maximizes the effectiveness of water-resource utilization, protection, and restoration.

Third, USGS programs recognize the interconnections between water quality and biological systems. USGS addresses the susceptibilities of specific aquatic organisms, such as algae, macroinvertebrates, and fish to water-quality degra- dation, and determines how biological responses vary among the diverse environmental settings across the Nation. Such assessments lead to improved biological monitoring and consistent methods for assessing water-resource and environmental results. In addition, USGS assesses microbial processes and their effects on chemical degradation and water-quality conditions.

Fourth, USGS water-quality programs evaluate water quality in an overall hydrologic context. Chemical and biological data for streams are interpreted within the context of streamflow measurements, and ground-water chemistry is interpreted with an understanding of the ground-water flow system and aquifer characteristics. This is important because contaminants and their potential effects on drinking-water supplies and aquatic habitats vary over time and largely depend on the amount of water flowing in streams and the directions of ground-water flow.

\section{USGS Complements the Work of Others}

USGS water-quality assessments characterize the ambient water resource, which is the source of the Nation's drinking water and of water for industrial, irrigation, and recreational uses. The USGS assessments thereby complement much of the compliance and regulatory monitoring conducted at the state level and by the U.S. Environmental Protection Agency (EPA) and other Federal agencies. Because of their regulatory responsibility, states and EPA typically focus on resources with the greatest levels of concern. This often makes it difficult for states and EPA to assess the total water resource. Also, state assessments are made against a backdrop of water-quality standards that differ from state to state. This makes regional and national assessments problematic. As water moves between and across state boundaries, the USGS has been able to provide information to multiple parties that are all interested in the same resource, but in different jurisdictional areas.

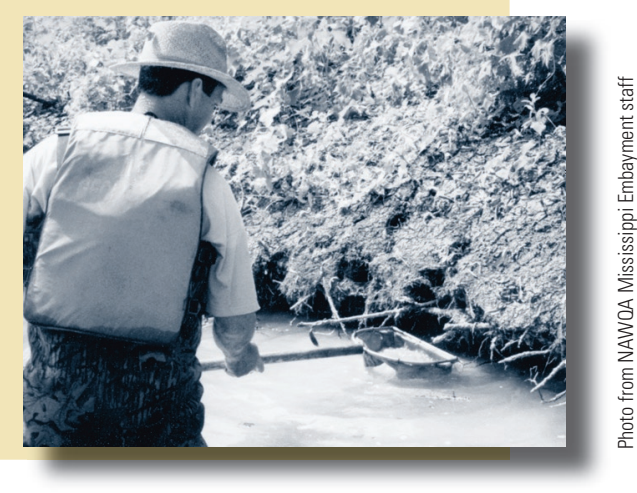


Fifth, USGS adheres to a national quality-assurance program with uniform methods of sampling and analysis. Monitoring data collected from representative sites across the Nation can, thereby, be combined into comprehensive regional and national assessments that identify and analyze trends in waterquality conditions.

Sixth, low levels of detection-often 10 to 1,000 times lower than EPA drinking-water standards - are used to allow an early warning of contaminants before they reach levels of regulatory concern. In addition, the low-levels of detection allow an improved understanding of the connections among sources, transport, and fate of chemicals_-generally not possible with data limited to measurements above regulatory levels.

\section{San Francisco Bay Long- Term Study}

Long-term studies conducted over 26 years in San Francisco Bay help resource managers and resource protection agencies understand the response of the Bay's aquatic community to the combined effects of climate variability, changes in the hydrologic system, and the introduction of organic contaminants and trace elements (http: //sfbay.wr.usgs.gov/).

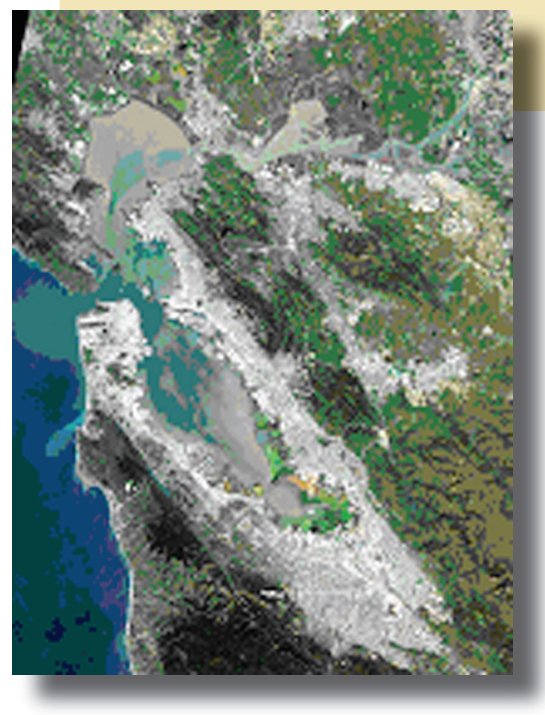

Landsat-7 image distributed by USGS EROS Data Center Distributed Active Archive Center

\section{Characteristics of USGS Water-Quality Programs:}

- Ambient water-resource evaluation over long time scales with a regional and national perspective

- Interactions among surface water, ground water, and the atmosphere

- Interconnections between water quality and biological systems

- Water quality in a hydrologic context

- Uniform methods of sampling and analysis

- Low-levels of chemical detection

\section{Long-Term Monitoring, Assess- ment, and Research Lead to Effective Water Management}

USGS has organized its programs around three key components that are critical for successful water-resource management, including 1) long-term monitoring, 2) resource assessment, and 3) research.

\section{USGS long-term data collection} provides a quantitative means to answer the question "Are things getting better or worse?" Water quality is constantly changing, from season to season and from year to year. Consistent and systematic information over the long term is needed to (1) distinguish long-term trends from short-term fluctuations and natural fluctuations from effects of human activities; (2) evaluate how environmental controls and strategies are working; and, (3) choose the most cost-effective resource strategies for the future.

USGS resource assessment addresses the many complexities of contaminant occurrence and transport, which vary seasonally and among watersheds because of differences in land use and chemical applications, land-management practices, degree of watershed development, and natural factors, such as soils, geology, hydrology, and climate. Even among similar land uses and sources of contamination, differences in hydrology and other natural factors can result in different degrees of vulnerability to contamination and different ways that water-management strategies can lead to improved water quality.

USGS research identifies emerging contaminants (such as pesticide degradates, hormones, steroids, and pharmaceuticals); provides new information and innovative study approaches for addressing contamination issues; and develops methodology for cost-effective hydrologic assessment. USGS continually improves techniques to understand and model sources and transport of contaminants, and processes affecting water quality in watersheds and aquifer systems. Continued development of reliable models helps to forecast the fate and transport of contaminants over different time frames, geographic areas, and environmental settings. Thus, improvements in modeling will help provide decisionsmaking tools needed by stakeholders at all levels to cost-effectively prioritize, manage, and protect their resource.

\section{MTBE Study}

USGS was first to document the national extent of occurrence of methyl tert-butyl ether (MTBE), a fuel oxygenate, in the environment. MTBE was added to gasoline in some parts of the country to help meet the goals of the Clean Air Act. Because MTBE entered ground and surface waters from leaking gasoline storage tanks and by other means, the addition of MTBE to gasoline had the unintended consequence of introducing a potentially harmful chemical into water resources (http://wwwsd.cr.usgs.gov/ nawqa/vocns/). 


\section{Case Study: Nutrient Transport in the Mississippi River Basin}

USGS studies of nutrient transport in the Mississippi River basin provide a good example of how insights obtained from the integration of long-term monitoring, resource assessment, and research can help to better understand an important regional and national water-quality issue. Excessive nitrogen in parts of the Mississippi River Basin threatens wildlife habitat, recreation, and drinking-water quality. The use of fertilizers is among the human factors that cause excess

\section{Microbiological Studies}

Microbiological studies led to the identification of processes that significantly affect the distribution of toxic metals, such as arsenic, selenium, and mercury. Research studies of methyl mercury formation have provided important insights into the microbial action and chemical reactions that affect the forms of mercury and, thus its toxicity, in aquatic ecosystems. nitrogen in the Mississippi River Basin, along with wastewater discharges and atmospheric deposition. In addition, channelization and loss of wetlands have decreased the degree of natural transformation of nitrogen to innocuous gaseous forms (known as denitrification), which naturally reduces the amount of nitrogen transported in water. USGS monitoring at more than 40 watersheds throughout the Mississippi River Basin during 1980 to 1996 has helped to define the relative nitrogen yields from different parts of the watershed (defined as the amount of nitrogen leaving a square kilometer of land, calculated from annual loads of nitrogen going past a stream gage and the area above the gage).

Each spring, excess nitrogen transported in the Mississippi River to the Gulf of Mexico causes the formation of a hypoxic zone, an area of low dissolved oxygen concentrations (http: //wwwrcolka.cr.usgs. gov/midconherb/ hypoxia.html). The resulting lack of oxygen can cause stress or death in bottomdwelling organisms that cannot escape to more oxygen-rich areas of the Gulf. Data collected by university scientists (Rabalais and others, 1999) have shown that the size of the hypoxic zone has more than doubled since it was first systematically mapped in 1985 . USGS long-term monitoring of water quality and streamflow demonstrate that the amount of nitrogen delivered to the Gulf of Mexico by the Mississippi River also has increased since the late 1960s

(Goolsby and Battaglin, 2000). The amount of nitrogen delivered to the Gulf varies from year to year because of flow conditions. For example, the amount was low during the drought in the late 1980s but extremely high during the flood of 1993, even though the amount of nitrogen applied to fields in the basin was not significantly different.

In addition to monitoring, USGS conducts research and special assessments on processes that affect nitrogen transport and transformation in small watersheds and large river channels throughout the Mississippi River Basin. The research provides increased understanding of how subsurface flow, atmospheric cycling, and different channel sizes affect whether nitrogen is transformed to different chemical forms, is transported downstream, or dissipates to the atmosphere. USGS scientists developed the mass-balance regression model known as SPARROW (for SPAtiallyReferenced Regression On Watershed attributes) to better understand the links between sources of contaminants and factors that affect downstream transport (http://water.usgs.gov/nawqa/sparrow). The method correlates stream nitrogen flux (the mass of nitrogen transported downstream past a point on a river) with upstream nitrogen inputs (such as fertilizer use, manure, wastewater discharges, and atmospheric

\section{Techniques for Age Dating Ground Water}

USGS pioneered the use of several techniques for age dating ground waters to identify sources of water within an aquifer, and to assess its vulnerability to contamination. Tritium was first used by the USGS for age dating in 1959. A similar technique was applied to chlorofluorocarbons (CFCs) to date recent ground water. The age dating techniques have produced important insights on sources of water and on understanding human impacts on its quality. For example, the age-dating findings demonstrated that improvements in ground-water quality, such as on the Delmarva Peninsula, may not be evident for years or even decades after farmers change their land-management practices because of slow ground-water movement (http://water.usgs.gov/lab/cfc/).

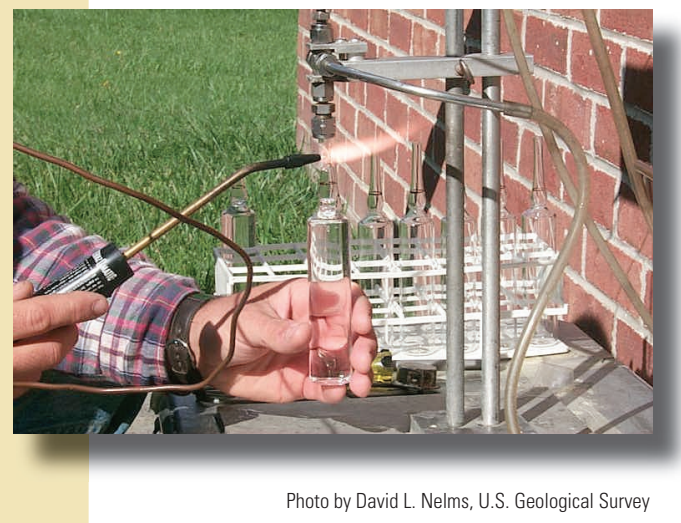


deposition) and with factors controlling nitrogen transport in watersheds, including landscape and basin characteristics (such as soil permeability, channel size, and water velocity). Results show that nitrogen removal in streams declines rapidly as channel size increases (Alexander and others, 2000). The proximity of nitrogen sources to large streams and rivers, therefore, increases the ultimate transport of nutrients to the Gulf of Mexico. Despite the long travel times, many watersheds located along large rivers more than 2,500 kilometers from the Gulf of Mexico deliver significantly larger fractions of nitrogen to coastal waters than watersheds located on smaller streams less than a few hundred kilometers from the Gulf. The delivery of nitrogen to coastal systems from point and nonpoint sources, therefore, is not a simple function of the distance of these sources from coastal waters.

USGS monitoring, assessment, and research in the Mississippi River Basin continues to have important implications for nutrient management. The information is used by states, federal

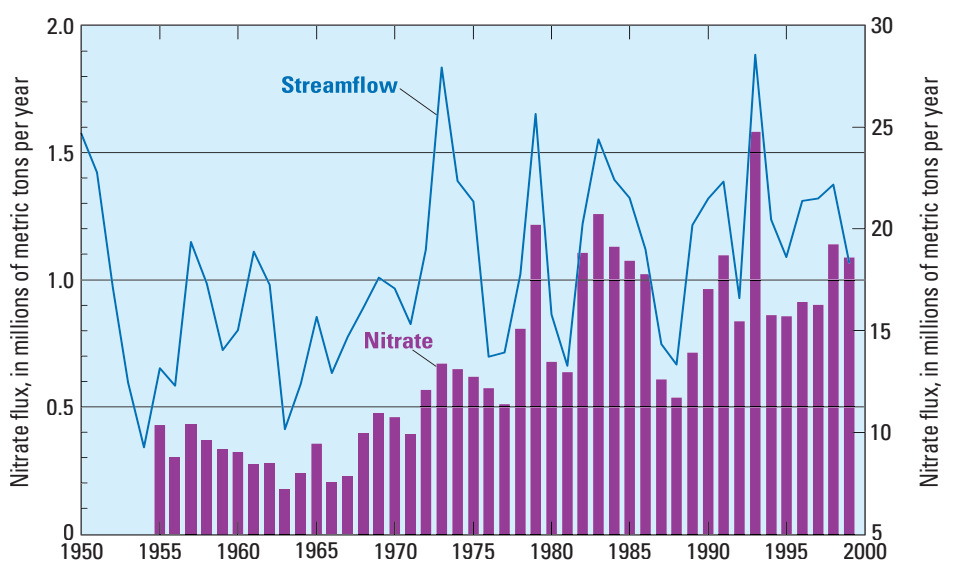

The total amount of nitrate delivered by the Mississippi River depends on the concentration of nitrate in the water and the amount of water flowing in the river (Goolsby and Battaglin, 2000; http://ks.water.usgs.gov/Kansas/pubs/fact-sheets/fs.135-00.html).

agencies, and other watershed stakeholders to develop and evaluate strategies for improved water-quality conditions. Specifically, the information is used to (1) help reduce nutrient losses from agricultural fields, urban runoff, and wastewater discharges; (2) guide wetlands restoration efforts and management of navigation control structures to increase denitrification; and, (3) identify watersheds with significant contributions of nitrogen and where nutrient management strategies might have the most cost-effective opportunity for improvement.

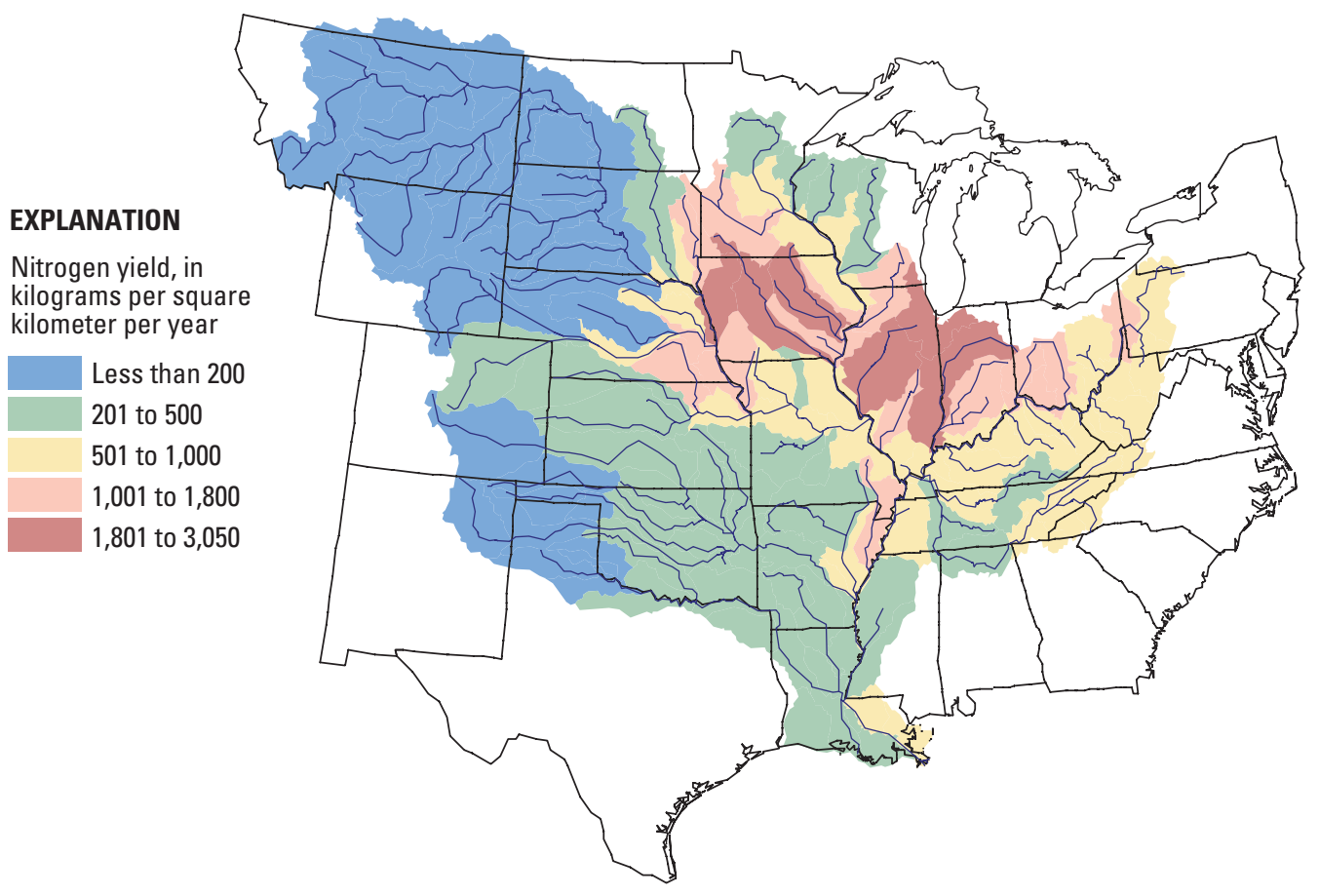

More than 4,000 water-quality measurements and continuous streamgaging at 42 representative watersheds during 1980 to 1996 were used to define the relative nitrogen yields from different areas within the Mississippi River Basin (Modified from Goolsby and Battaglin, 2000; http://ks.water.usgs.gov/Kansas/pubs/factsheets/fs.135-00.html). 


\section{USGS Water-Quality Programs}

USGS water-quality programs are designed to support the three components described above-monitoring, resource assessment, and research needs of the nation-although, generally each program tends to emphasize one component over the others. Each of the six programs are independently managed and funded; however, USGS organizes and integrates the different activities over time and across the Nation to capitalize upon existing resources. Resources are furthered leveraged through the collaboration and coordination with a multitude of federal, state, and local agencies, universities, public interest groups, and the private sector. Collaboration and coordination also help to guide and complement USGS scientific efforts and ensure that USGS information meets the needs of local, state, regional, and national stakeholders.

National Water-Quality Assessment Program (NAWQA), which began in 1991 , focuses on water quality in 42 major river basins and aquifer systems, referred to as "study units." A study unit boundary frequently crosses state boundaries and usually encompasses

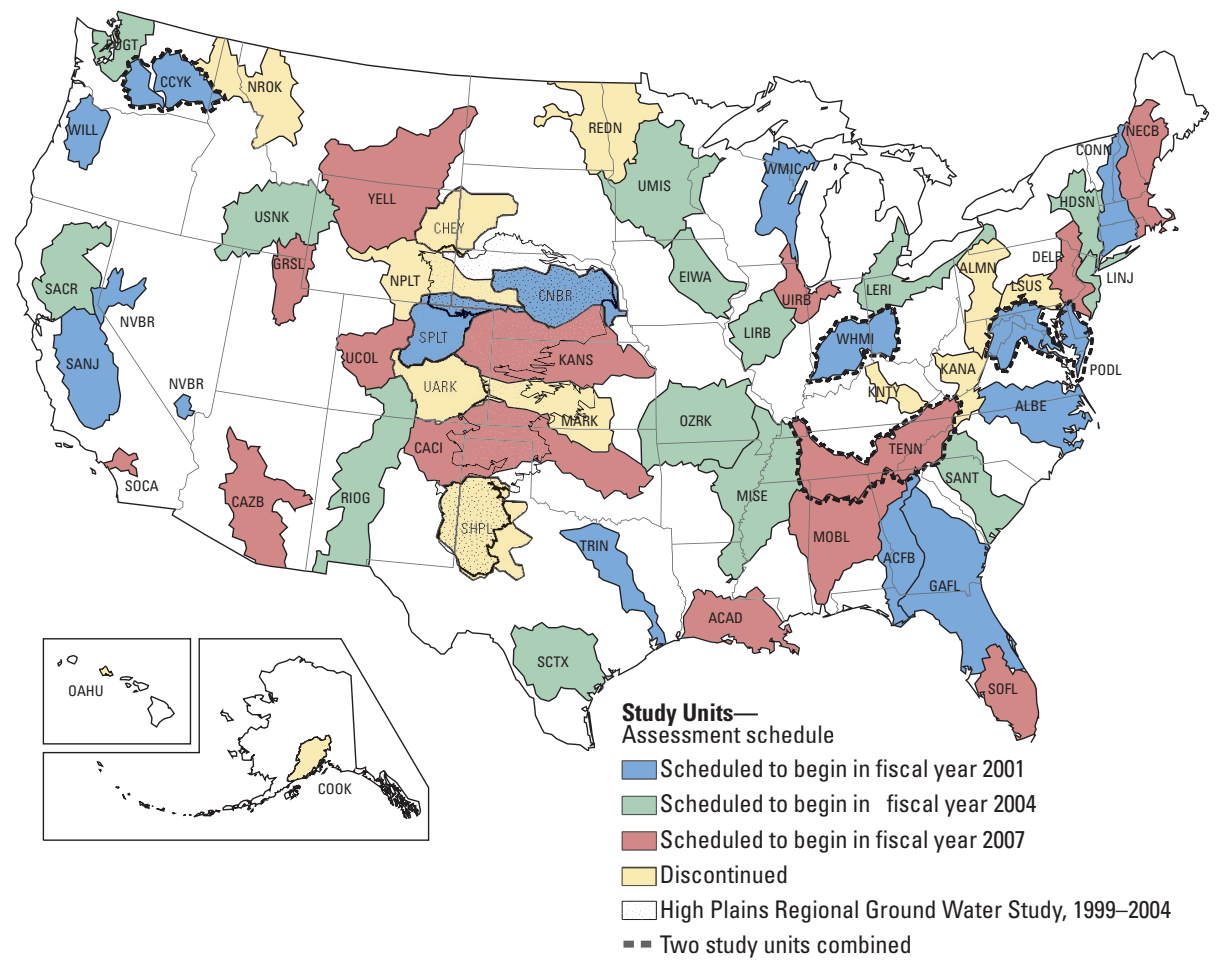

The National Water-Quality Assessment (NAWOA) Program assesses water-quality conditions in 42 major river basins and aquifer systems across the Nation (http://water.usgs.gov/nawqa). in the Gulf of Mexico, and effects of mercury on aquatic ecosystems in the Everglades, Florida. Long-term research sites and regional- and national-scale monitoring networks provide a framework for interdisciplinary research teams that include non-USGS scientists. New methods are developed to make environmental measurements at low levels and to assess emerging water-quality issues, such as pharmaceuticals, hormones, and other wastewater contaminants. Models are developed to predict the transport and fate of contamination and to evaluate water-quality conditions under different management scenarios. For additional information, see http: //toxics.usgs.gov.

The Cooperative Water program (COOP), which began in the early 1900's, includes studies in every state, protectorate and territory of the United States. These studies are conducted in cooperation with about 1,400 state and local agencies, which provide at least half of the funding. The studies generally focus on local (county or multiple counties) and State issues, related to, for example, development of water quality and biology monitoring networks, source-identification of contaminants, effects of watershed development on quality and aquatic life, use of alluvial aquifers as public water supplies, pathogens and pathogen indicators, effects of animal feeding operations, and development of models and other analytical assessment tools. Because USGS waterquality studies incorporate streamflow measurements, many of the data collected at the local and State scales in the COOP projects are useful in the development of Total Maximum Daily Loads (TMDLs) for impaired stream reaches. For additional information see http: //water.usgs.gov/coop.

Hydrologic Benchmark Network (HBN), which began in 1964, is comprised of stations across the Nation in areas with minimal influence from human activities. The HBN covers about 55 watersheds, ranging from a few to 50 square miles. Primary influences on water flow and quality at HBN sites are atmospheric inputs and the natural geologic conditions. HBN water- 


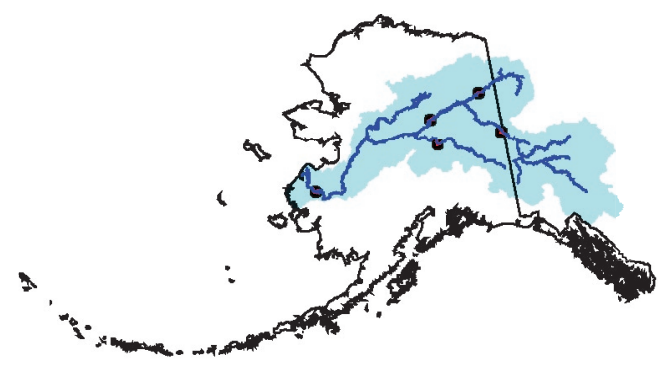

EXPLANATION
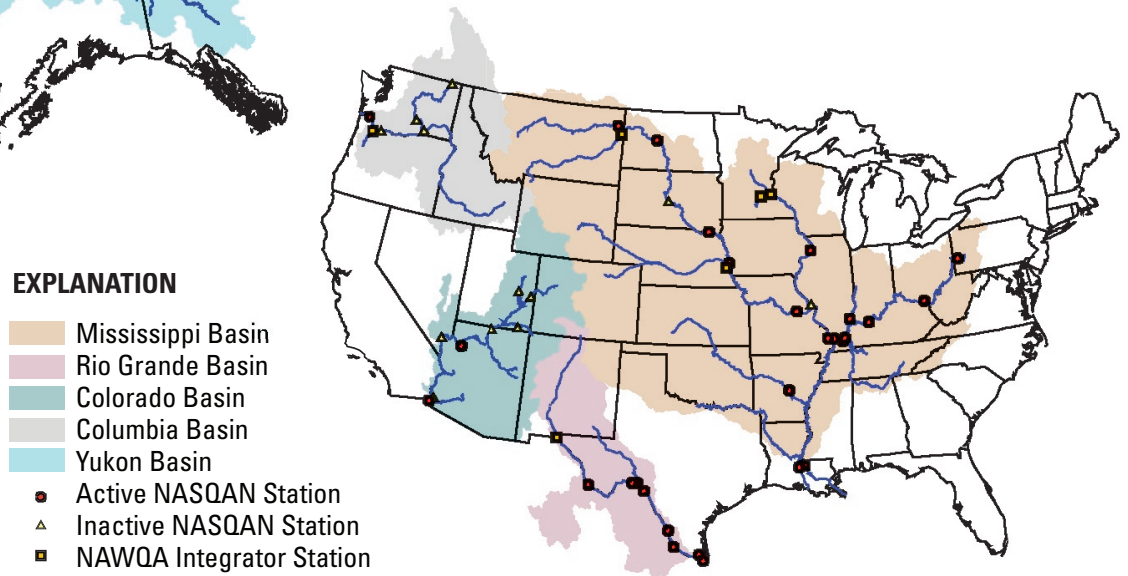

USGS measures water quality in five of the Nation's largest river basins through its National Stream Quality Accounting Network (NASQAN) (http://water.usgs.gov/nasqan).

sheds are used to assess influences from atmospheric emissions regulated through the Clean Air Act. For additional information see http://water.usgs.gov/hbn.

National Stream Quality Accounting Network (NASQAN) was established in 1973. Currently the program measures the flux and transport of selected compounds in five of the Nation's largest river basins (ranging from 250,000 to $1,200,000$ square miles), including the Mississippi River, Columbia River, Colorado River, Rio Grande, and the

\section{USGS Data Are Readily Available}

The large USGS database on water-quality conditions and other information is publicly available and can be readily accessed via the Internet (http://water.usgs.gov/ nwis). It includes chemical data from rivers, streams, lakes, springs, and ground water from more than 335,000 sites, streamflow data from more than 20,000 sites, and water levels from more than 1 million wells. Selected field measurements, such as $\mathrm{pH}$, temperature, and specific conductance, are available in real-time (updated at intervals of 4 hours or less) at more than 800 USGS sites.
Yukon. NASQAN data help to identify major source areas of contaminants and natural constituents, how they are transported and accumulated downstream, and areas of major deposition within the river basin. For additional information see http://water.usgs.gov/nasqan.

National Trends Network (NTN), which began in 1983, is part of the National Atmospheric Deposition Program. The network is operated in collaboration with more than 100 Federal, State, local, and private sector organizations. The NTN Program provides regional and national information on atmospheric deposition on the land surface through the collection of precipitation samples and analysis for major ions and nutrients at more than 240 sites. A major benefit of NTN has been identification of the acidity of atmospheric deposition and changes in precipitation chemistry as a result of Clean Air Act reductions in the emission of oxides of nitrogen and sulfur. A subnetwork of NTN sites is used to monitor mercury deposition from precipitation. For additional information see http: //bqs.usgs.gov/acidrain.

\section{References Cited}

Alexander, Richard B., R.A. Smith and G.E. Schwarz, 2000. Effect of Stream Channel Size on the Delivery of Nitrogen to the Gulf of Mexico. Nature 403: 758-761.
Goolsby, D.A. and W.A. Battaglin, 2000. Nitrogen in the Mississippi River Basin-Estimating Sources and Predicting Flux to the Gulf of Mexico. U.S. Geological Survey Fact Sheet 135-00 (http://ks.water.usgs.gov/ Kansas/pubs/fact-sheets/fs.13500.html).

Rabalais, N.N., R.E. Turner, J. Dubravko, J., Q. Dortsch, and W.J. Wisman, Jr., 1999, Characterization of Hypoxia-Topic 1 Report for the Integrated Assessment on Hypoxia in the Gulf of Mexico: Silver Spring, Md., NOAA Coastal Ocean Office, NOAA Coastal Ocean Program Decision Analysis Series No. 17, 167 p.

By Gail E. Mallard and Pixie A. Hamilton Layout and design by Phillip J. Redman

Visit our Web site at

http://water.usgs.gov for direct access to reports and other interpretive information, monitoring data, technical reports, and maps.

\section{For additional information, please contact:}

Chief, Office of Water Quality

Programs, USGS

(703) 648-5716 (voice)

(703) 648-6693 (fax)

nawqa_info@usgs.gov 